Lena Lind Palicki

Språkvårdare, fil.dr

Språkrådet, Institutet för språk och folkminnen

Andreas Nord

Universitetslektor, docent

Institutionen för svenska språket, Göteborgs universitet

\title{
Från demokratisk rättighet till tips och småknep i skrivandet Några nedslag i det svenska klarspråksarbetet
}

\begin{abstract}
Plain Swedish is often described as a well-established project whose aim it is to create simpler and more reader-friendly public administration texts, in order to promote democratic transparency; however, the practical operationalisation of this language-planning project have been only sparsely studied. The current study draws on the Language Policy and Planning tradition, to investigate the relationship between the political discourse on Plain Swedish in language-policy documents and its operative side, especially as seen in marketing materials from small commercial providers of Plain Swedish services and in a short course offered at municipal offices. The results indicate that the ideological aspects of the political Plain Swedish effort are barely recognizable at the micro level, since its democratic aspects are virtually absent. Instead, arguments tend to reference efficiency, cost reductions, and other benefits for the individual writer. This study concludes by arguing that the Plain Swedish project may lose its validity if it is consistently reduced to resolving individual authors' 'here and now' problems, rather than inspire a more ideological change in writing practices.
\end{abstract}

\section{Sammandrag}

Klarspråk beskrivs ofta som ett väletablerat projekt som syftar till att skapa enklare och mer läsarvänliga myndighetstexter, med målet att uppnå demokratisk insyn. Det praktiska genomförandet av detta språkplaneringsprojekt har dock bara studerats sporadiskt. Artikeln utgår från forskning om språkplanering för att undersöka relationen mellan den politiska diskursen om klarspråk i språkpolitiska dokument och dess genomförandepraxis, såsom den realiseras $i$ marknadsföringsmaterial från företag som erbjuder klarspråkstjänster och $i$ en kort kurs vid ett kommunkontor. Resultaten visar at den ideologiska aspekt som framträder i den politiska diskursen om klarspråk är svår att identifiera på mikronivå, eftersom demokratiaspekten där nästan helt har trätt $i$ bakgrunden. I stället används motiveringar grundade på effektivitet och minskade kostnader och andra fördelar för den enskilda författaren. I artikelns avslutning diskuterar vi därför om klarspråksprojektet riskerar att tunnas ut och förlora sin legitimitet 
om det konsekvent reduceras till att lösa de enskilda författarnas problem "här och nu" snarare än att inspirera till mer ideologiskt grundade förändringar i skrivpraktiker.

Vid en ytlig betraktelse kan den svenska myndighetsspråkvården förefalla som ett homogent projekt med konsensus om mål och mening. Många formuleringar som sammanfattar det som i dag ofta benämns "klarspråk" är påfallande likartade. Ett ganska typiskt exempel är följande förklaring som finns på hemsidan för det svenska Språkrådet, som har som ett av sina ansvarsområden att stödja myndighetsspråkvården:

Klarspråk står för myndighetstexter skrivna på ett vårdat, enkelt och begripligt språk. Klarspråk handlar ytterst om demokrati: att alla ska ha tillgång till och rätt att förstå vad som står i texter som skrivs av myndigheterna. (Språkrådet odaterat)

Den första delen av förklaringen, "vårdat, enkelt och begripligt språk”, återspeglar den formulering som valdes i den svenska språklagen (SFS 2009:600). I den slår den elfte paragrafen fast att "[s]pråket i offentlig förvaltning ska vara vårdat, enkelt och begripligt". Detta ersatte en äldre formulering i förvaltningslagen (SFS 1986:223), där sjunde paragrafen beskrev ungefär samma krav: "Myndigheten skall sträva efter att uttrycka sig lättbegripligt. [...]". Den andra delen av Språkrådets förklaring tar fasta på en av de vanligaste motiveringarna av myndighetsspråkvården, nämligen demokratikravet att alla ska ha rätt att förstå myndigheternas texter.

Språkrådets formulering visar rätt väl hur detta språkpolitiska projekts fokus och syfte brukar sammanfattas utifrån kravet på begriplighet och hänsynen till demokrati. Men vad händer när det ska förverkligas? Detta är inte lika självklart. Forskning om andra typer av språkbruksförändrande projekt har visat att ett projekts genomförande i hög grad påverkas (och förändras) av de lokala förutsättningarna. Det finns visserligen bara få studier av genomförandet av språkpolitiska projekt knutna till offentliga texter (Kjærgaard 2010, 2012, Bendegard 2014, 2015), men dessa indikerar att klarspråksprojekt inte är något undantag - på lokal nivå omformas de i hög grad av de förutsättningar som gäller i genomförandekontexten. Detta är förstås helt naturligt. Den typ av normativa formuleringar som vi citerade ovan är ju alltför allmänt hållna för att kunna omsättas direkt i ett visst språkligt handlande, och i likhet med alla politiskt grundade beslut krävs det många steg av operationalisering, där varje steg förutsätter en ny anpassning till lokala förutsättningar. Så vad blir följderna när ett visst politiskt ideal ska omsättas i praktiskt arbete? Vilka är problemen, och vilka är riskerna när detta språkpolitiska projekt ska genomföras?

I denna artikel vill vi ge några bidrag till en övergripande beskrivning av det väletablerade praktiska språkvårdsarbetet på svenska myndigheter genom att sätta det i relation till beskrivningar av den politiska dimensionen. Det saknas nämligen ännu, som vi redan har antytt, studier av hur det som ofta sammanfattas under benämningen klarspråk egentligen realiseras. Vårt bidrag tar sig uttryck i tre nedslag i olika delar av språkvården - i politiska dokument, i marknadsföringstexter, och i en utbildning hållen på en kommunförvaltning och vi tar vår utgångspunkt i följande två övergripande frågor: 
1. Hur används benämningen "klarspråk"?

2. Hur motiveras strävan efter ett enklare (myndighets)språk?

Genom dessa frågor kan vi dels belysa funktionen i den benämning som i dag har börjat få fäste som etikett på språkvårdsarbetet, alltså "klarspråk", dels belysa hur arbetet underbyggs genom olika typer av motiveringar. I slutet av artikeln kommer vi också att diskutera några implikationer av det vi har sett, för att problematisera vad som händer i detta språkpolitiska arbete när det omsätts i praktiskt genomförande.

\section{Forskningssammanhang}

Arbetet för ett enklare myndighetsspråk utgör ett språkplaneringsprojekt, om språkplanering förstås enligt Robert L. Coopers (1989) vida definition: "deliberate efforts to influence the behavior of others with respect to the acquisition, structure, or functional allocation of their language codes" (s. 45). Coopers definition öppnar för att i princip vilken social aktör som helst kan vara agent i en språkplaneringsprocess (och Cooper exemplifierar också med sådana processer). I dag har det dock blivit vanligare att tala om language policy eller language policy and planning, och då lite snävare fokusera på processer initierade i politiska kretsar ${ }^{1}$. Det svenska klarspråksarbetet passar även in på denna lite snävare definition, eftersom det har sin grund i politiska beslut. Det finns en politisk vilja och ett politiskt aktörskap som initierar och sanktionerar klarspråk, bl.a. genom lagstiftning.

Ser vi mer i detalj på det svenska klarspråksarbetet och dess grunder har vi dock förvånansvärt lite systematiserad, vetenskaplig kunskap. I handledningar om klarspråksarbetet ingår ibland historiker över klarspråksarbetet, sannolikt med syftet att påvisa dess hävd och starka etablering och understryka att det historiskt sett har sitt ursprung i motstånd mot snårigt kanslispråk (Visst går det att förändra myndighetsspråket! 1993, Klarspråk lönar sig 2006, s. 28). Några mer vetenskapliga historiker finns också skrivna (Teleman 2003, 2005, Nämnd, inte glömd 2007 m.m.). Dessa pekar bl.a. ut detta språkpolitiska projekts samband med den växande välfärdsstaten med ökade kontakter mellan tjänstemän och medborgare (Teleman 2003, s. 1977) och med den strävan efter ett mer jämlikt språk som kännetecknat de senaste decennierna. I de vetenskapliga historieskrivningarna kan man tydligt se att det redan tidigt finns en etablering av de grundläggande tankarna, där det är den enskilda medborgarens intresse av ett lättillgängligt språk som står i centrum.

Utöver beskrivningar av klarspråksarbetets historik finns det en rikhaltig flora av handbokslitteratur som sammanfattar praktiska erfarenheter och ger beskrivningar av goda exempel på genomförandeinsatser. Schriver \& Gordon (2010) benämner i en inventering av forskning av relevans för Plain Language - den anglosaxiska motsvarigheten - detta som “informal research". Sådan forskning har dock sällan något egentligt vetenskapligt värde och innehåller så gott som aldrig någon djupare teoretisk reflektion. ${ }^{2}$ Ett skäl till bristen på mer

\footnotetext{
${ }^{1}$ I gengäld omnämns ofta projekt för att styra språket i t.ex. företag och organisationer som language management.

${ }^{2}$ Några nordiska exempel är Visst går det att förändra myndighetsspråket! 1993, Texter för medborgarna - hur vet man om de är bra? 2005, Klarspråk lönar sig 2006, 2013, och Jarvad \& Mørch 2007.
} 
systematiskt genomförd forskning om klarspråksarbetet kan vara att denna typ av språkplanering nästan helt är professionsbaserad och att kopplingen mellan forskning och praxis varit svag (Nyström Höög 2009, 2010). Detta är något förvånande. Sverige har en unikt lång tradition av högskoleutbildning på området - akademiska språkkonsultutbildningar har funnits ända sedan 1978 (jfr Hjalmarsson \& Nicolay 2010) och finns i dag på fyra svenska universitet. Behovet av fördjupande forskning om klarspråksarbetet och dess praxis har flera gånger pekats ut (Josephson 2009, Nyström Höög, 2009, Nyström Höög, Söderlundh \& Sörlin 2012a), men det är först under senare år som detta har börjat hörsammas. De studier som har genomförts är ganska begränsade, men erbjuder dock en viss bakgrund och framför allt en god grund för att bilda hypoteser.

Ser man till ett skandinaviskt sammanhang är det viktigaste bidraget till forskning om klarspråk Anne Kjærgaards avhandlingsstudie om effekterna av klarspråksprojekt på två danska myndigheter (Kjærgaard 2010, 2012). Kjærgaard ställer här en effektmätning av förändringen i texter skrivna på myndigheten mot en organisationsanalys av förutsättningarna på samma myndigheter, och kan påvisa att bristande förankring i organisationen på lokal nivå leder till ytterst begränsade effekter på de texter som skrivs. Ett annat viktigt bidrag finns ett par fallstudier av språkvårdares språkgranskning av myndighetstexter utförda av Nord (2011a, b, 2013). Här framkommer att språkvårdares arbete att göra texter mer läsarvänliga inte självklart tas väl emot av skribenter med annorlunda textideal, men också att många traditionella språkliga råd inom klarspråksarbetet är mindre meningsfulla för mer avancerade facktexter. Även Bendegard visar i sin avhandlingsstudie av EU-översättningar $(2014,2015)$ hur de lokala förutsättningarna påverkar möjligheterna för klarspråksarbete. Ett återkommande resultat i dessa studier är att de lokala villkoren spelar mycket stor roll för utfallet av klarspråksinsatser.

Utifrån erfarenheter inom språkplaneringsforskningen är det inte oväntat att de lokala villkoren har avgörande betydelse. Forskning om andra typer av språkplaneringsprojekt har på senare tid allt oftare lyft fram just de lokala förutsättningarnas stora roll för möjligheterna att styra och planera språkbruk. Även om denna forskning berör andra typer av språkplaneringsprojekt än förändring av myndigheters språkbruk finns här iakttagelser värda att beakta. Studier av t.ex. språkval och språktillägnande i mångspråkiga kontexter har på senare år allt oftare innefattat etnografiska mikrostudier, som har belyst hur villkoren på lokal nivå är en väsentlig aspekt av språkplaneringen (se exempelvis Spolsky 2004, Baldauf 2006, Canagarajah 2006, Hornberger \& Johnson 2007, Berthoud \& Lüdi 2011). T.ex. är en viktig iakttagelse att om politisk vilja hamnar i konflikt med lokala, praktiska förutsättningar så är det de lokala, praktiska förutsättningarna som tenderar att ta överhanden. Hornberger \& Johnson (2007, s. 511) sammanfattar en viktig utgångspunkt så här:

Historical and intertextual analyses of policy texts can capture the confluence of histories, attitudes, and ideologies that engender a language policy but, alone, cannot account for how the creation is interpreted and implemented in the various contextual layers through which a language policy must pass. 
För att synliggöra de processer som initieras på lokal nivå, talar Baldauf (2006) om hur politiska planeringsinsatser i genomförandet kan mötas av mikromotstånd (micro resistance). Om det finns en motsättning mellan planen på makronivå och förutsättningarna $\mathrm{i}$ den lokala situationen kan detta hanteras av enskilda aktörer genom motstånd mot planen (se Baldauf 2006, s. 157 f. för exempel). Planeringsinsatser kan också möta andra språkliga planeringsprojekt, exempelvis sådana där lokala aktörer arbetar för att lösa deras egna, lokala språkliga behov på ett sätt som kan hamna i konflikt med mer övergripande språkplaneringsprojekt (se Baldauf 2006, s. 154). Resultatet av detta möte kan göra att det politiska språkplaneringsprojektet transformeras och anpassas. Det kan också handla om andra typer av hinder för genomförande, där motståndet inte är aktivt eller medvetet utan snarare handlar om lokala konventioner, attityder, språkbrukarnas kompetens eller förhållningssätt (jfr Kjærgaard 2010, 2012, Becker Jensen 1998, 2007). Motstånd behöver alltså inte tolkas som ett aktivt ställningstagande, utan kan också förstås som icke-förändring inom en rutiniserad praktik.

\section{Material}

För att belysa några aspekter av klarspråksarbetet kommer vi att göra nedslag i material från tre olika kontexter: dels i språkpolitiska dokument, dels i sammanhang där klarspråksprojektet förväntas möta andra, lokala språkprojekt, nämligen marknadsföringsmaterial om produkter med relevans för "klarspråk" från språkvårdsföretag samt i en kort utbildning på en kommunal förvaltning.

Det första nedslaget sker i den politiska sfären, vilket är naturligt när vi vill se hur språkpolitiska ställningstaganden omsätts i genomförande. Vi har gått igenom propositioner och betänkanden (utredningar) på det språkpolitiska området från två perioder: dels undersöker vi de förarbeten som ledde fram till den första lagformuleringen om myndigheters språk i förvaltningslagen, inklusive ett kommittédirektiv, dels de olika språkutredningarna från 2000-talet, som avslutades med förarbetena till språklagen (se under "Analyserat politiskt material" i referenslistan). ${ }^{3}$

Det andra nedslaget sker i fyra språkvårdsföretags marknadsföringsmaterial. Vi har valt företag som kan antas vara viktiga aktörer i genomförandet eftersom de ofta anlitas av myndigheter som inte har egna språkvårdare anställda. Vi ser här på hur företagen presenterar sig själva och sina tjänster av typen utbildningar och språkgranskning på sina webbplatser. Särskilt utmanande för detta material är att det språkpolitiska projektet behöver paketeras som produkter som säljs på kommersiella villkor, vilket ställer behovet av motivering på sin spets. Vi kommer att hänvisa till materialen utifrån vilken typ av material det är (produktblad för utbildning, webbsida med självpresentation etc.) och det utgivande företaget benämns "Företag 1" etc. (se under “Analyserat material från språkvårdsföretag” i referenslistan).

\footnotetext{
${ }^{3}$ Potentiellt intressanta material från den politiska sfären vore även riksdagsdebatt, remissvar på utredningar och politiska tal etc. Analyser av sådana material har gjorts i en tidigare studie (Nord 2014), som vi hänvisar till för dessa resultat. Genomgången där visar bl.a. att "klarspråk" är en mycket marginell fråga i det senaste decenniets svenska riksdagsdebatt, liksom att remissvaren nästan alltid är bifall.
} 
Till sist analyserar vi även en halvdagsutbildning hållen av en erfaren språkvårdare på en kommunal förvaltning. ${ }^{4}$ Just denna typ av utbildningar har ofta setts som ett viktigt verktyg för att ändra skrivvanor (se t.ex. Klarspråk lönar sig 2006, s. 20), och utgör ett av de mest konkreta exemplen på möten mellan språkplaneringsarbetets professionella utförare - i detta fall en frilansande specialist - och de som förväntas genomföra det genom att förändra sin praxis. I vår analys av utbildningen har vi framför allt använt en transkriberad videoinspelning av utbildningen med fokus på kursledaren, en intervju med en deltagare i klarspråksutbildningen och en intervju med kursledaren.

Utbildningen är fristående utan särskilda förkunskapskrav och de ungefär femton deltagarna arbetar alla på den aktuella förvaltningen. Det är frivilligt för dem att delta och några av dem har tidigare deltagit i liknande utbildningar. Själva utbildningen hålls i den kommunala förvaltningens egna lokaler. Den har i hög grad formen av föreläsning med inslag av hårt styrd diskussion om textexempel ("övningar") ledda av kursledaren. Kursdeltagarna interagerar med kursledaren genom att svara på frågor, men tar få initiativ till att introducera nya samtalsämnen eller ställa frågor. I de fall sådana förekommer är de tydligt relaterade till själva utbildningen och utgör snarast följdfrågor. Kursledaren uppfattar utbildningen som "typisk" för korta utbildningar i skrivande inom offentlig förvaltning.

Utbildningen har delvis skräddarsytts genom att delar av exempelmaterialet hämtats från texter som deltagarna själva har sänt in i förväg, men i huvudsak är det en generellt hållen kurs, som sträcker sig över områden som arbetssätt (skrivprocess), mottagaranalys/ mottagarmedvetenhet, övergripande textstruktur och mycket detaljerade språkråd.

Vi har alltså valt våra tre nedslag strategiskt. Även om det vi här talar om som myndighetsspråkvård är mångfasetterat och komplext, bör vår undersökning trots sina begränsningar kunna ge ett intressant underlag för att diskutera och problematisera vad som händer i detta arbete när det möter lokala förutsättningar. Vi hävdar emellertid inte att de iakttagelser vi gör är generaliserbara.

Som kommer att framgå kan det också ifrågasättas om de nedslag vi gör verkligen fångar något som överhuvudtaget är meningsfullt att definiera in i det statligt sanktionerade politiska språkprojektet. Vi kommer att återvända till en problematiserande diskussion om detta i slutet av artikeln.

\section{Benämningarna klarspråk och klarspråksarbete}

Vi startar genom att se på de båda benämningarna klarspråk och klarspråksarbete. Förståelsen av dessa kommer att visa sig ha betydelse: dels har de förändrats över tid, dels används de i många fall på ett sätt som man kan kalla taktiskt. Hur dessa benämningar används - eller inte används - i delmaterialen ger därför ett intressant perspektiv på hur klarspråksarbetet anpassas till förutsättningarna i lokala kontexter. Vi börjar med en bakgrund för att sedan gå över till att visa hur benämningarna används i de olika materialen.

Vi har hittills ganska förenklat behandlat klarspråk och klarspråksarbete som samlande etiketter för språkplaneringsarbetet inom offentlig förvaltning. Detta är delvis anakronistiskt,

\footnotetext{
${ }^{4}$ Resultat från denna undersökning har tidigare redovisats i Lind Palicki \& Nord 2013 och i Lind Palicki 2014.
} 
eftersom benämningarnas historia inte alls är lika lång som själva arbetet för ett mer mottagaranpassat myndighetsspråk. Enligt ett försök att utreda historien av Nyström Höög, Söderlundh \& Sörlin (2012b, s. 35) kan klarspråk härledas till ett firmanamn på ett språkvårdsföretag under 1980-talet men också till titeln på den utredningsrapport som Språkvårdsutredningen lade fram 1985: Klarspråk - en grund för god offentlig service. Det dröjer dock innan benämningen slår igenom. I rapporten Visst går det att förändra myndighetsspråket! (1993), framtagen från ett språkvårdsprojekt, används det t.ex. inte alls. Det är inte förrän under 1990-talet som det verkar bli mer etablerat som svensk motsvarighet till engelskans Plain Language eller Plain English. Draghjälp ges av att språkvårdarna på regeringskansliet 1994 bildar "Klarspråksgruppen" och att dess nyhetsbrev får beteckningen "Klarspråksbulletinen". Under 2000-talet börjar klarspråk förekomma även i propositioner och utredningar.

Själva benämningen verkar också i dag tillmätas en viss betydelse; t.ex. utarbetade år 2013 två intressegrupper i Sverige definitioner av "klarspråk" respektive "klarspråksarbete", vilka sedan dess finns i den svenska Rikstermbanken (sökord: klarspråk och klarspråksarbete). Dessa definitioner är dock ganska allmänt och brett hållna - klarspråk definieras t.ex. som "språk som dels är tydligt, dels är begripligt för de avsedda mottagarna". Samtidigt följs definitionen av "klarspråk" av en mycket lång anmärkning där bl.a. tydligt språk, begripligt språk och de avsedda mottagarna definieras. Intressant här är just att räckvidden i beteckningen klarspråk berörs, liksom räckvidden i det som i kommentaren betecknas som "klarspråksprinciperna" (vilket får förstås som den kanoniska uppsättning råd som brukar traderas - se Nord 2011a, kap. 4). Det slås här fast att klarspråk och "klarspråksprinciperna" har sitt ursprung i myndighetsspråkvården men att de också kan användas "inom andra typer av organisationer":

Termen klarspråk och klarspråksprinciperna har vuxit fram inom myndighetsvärlden som ett steg i att demokratisera kommunikationen mellan det offentliga och medborgarna. Klarspråk kan dock användas även inom andra typer av organisationer och ska alltså inte tolkas som bundet till offentliga texter. (Rikstermbanken, sökord: klarspråk)

Detta kan tyckas något motsägelsefullt, men speglar sannolikt en aktiv strävan att vidga användningen av benämningen till kontexter utanför de traditionella.

\section{Benämningarna klarspråk och klarspråksarbete i språkpolitiska dokument}

I det politiska materialet kan vi snabbt konstatera att klarspråk som benämning inte förekommer i de äldre texterna, vilket bekräftar den ovan skisserade historiken. I 1980-talsmaterialet används det inte alls, bortsett från att Språkvårdsutredningens betänkande (1985) har ordet klarspråk som sin sammanfattande huvudrubrik (Klarspråk-en grund för god offentlig service).

I den stora utredningen Mål $i$ mun som lades fram av kommittén för svenska språket 2002 används benämningarna några gånger i förbigående som en sammanfattande beskrivning av språkplaneringssträvanden inom det offentliga, men har ingen viktig roll. I de senare dokumenten ges benämningarna en mer central roll. Dock presenteras de inte heller då som 
synonyma med själva språkplaneringsprojektet att förbättra myndigheters kommunikation och språkbruk, utan används snarast för att peka ut den (hävdvunna) operationaliseringen av det. I betänkandet där lagtextens formuleringar motiveras utvecklas detta på följande sätt:

Det är en självklar utgångspunkt för den offentliga verksamheten att språket som används ska kunna förstås av dem som berörs av åtgärder som vidtas eller beslut som fattas av domstolar, förvaltningsmyndigheter och andra företrädare för offentlig verksamhet. Detta, som brukar beskrivas som ett krav på klarspråk, uttrycks i $11 \S$ [av språklagen].

Kravet på klarspråk är inte nytt. Under många år har aktivt klarspråksarbete bedrivits vid ett stort antal myndigheter. (Värna språken - förslag till språklag 2008, s. 257, vår kursivering)

Här ser vi att ett visst ideal beskrivs som en "självklar utgångspunkt". Detta ideal framstår som det primära, och det ges sedan etiketten klarspråk på ett sätt som innebär en viss gardering (det "brukar beskrivas som ett krav på klarspråk"). Genomförandet benämns sedan som "aktivt klarspråksarbete". På ett annat ställe i samma betänkande kommenteras själva begreppet: "Begreppet klarspråk har under senare år kommit att stå för begripliga myndighetstexter och ett klart och mottagaranpassat myndighetsspråk" (Värna språken - förslag till språklag 2008, s. 110). Samma kommentar återkommer sedan i regeringens proposition om språklagen (Språk för alla - förslag till språklag 2009, s. 27). ${ }^{5}$

Således är benämningen klarspråk i dag tydligt och entydigt associerad med språkplaneringsprojektets demokratiideal, och klarspråksarbete används ofta för att referera till den hävdvunna operationaliseringen av idealet (jfr dock Nord 2014 om ifrågasättanden av själva operationaliseringen).

\section{Benämningen klarspråk $i$ språkvårdsföretags marknadsföringsmaterial}

Klarspråk och klarspråksarbete har alltså blivit etablerade benämningar i den politiska diskursen och används ofta för att referera till genomförandet. Paradoxalt nog visar sig benämningarna spela en mer svårfångad roll i kommersiella aktörers produktpresentationer. Förhållningssättet framstår här som ambivalent, vilket tar sig uttryck i att klarspråk visserligen ofta används, men då snarare i förbigående, utan att det framstår som centralt eller ideologiskt laddat eller ens som något annat än ett allmänt positivt laddat ord. Ett exempel är en kurs som heter "Klarspråk för juristen", som beskrivs på följande sätt i ett produktblad:

\section{Klarspråk för juristen}

Många kunder avstår från att anlita en jurist för att de är oroliga att de inte ska förstå. Låt ett klart och enkelt språk bli en konkurrensfördel för din byrå och en ledstjärna för din organisation. Börja med en skrivkurs hos [företagsnamnet].

\section{Vem vänder sig kursen till}

Kursen vänder sig till dig som arbetar med juridiska texter inom både privat och offentlig sektor, som vill få en metod för att förenkla och effektivisera skrivandet. (Ur produktblad för skrivkurs, företag 2)

\footnotetext{
${ }^{5}$ Formuleringen har uppenbarligen traderats mellan politiska texter. Den återfinns även i Klarspråk lönar sig (2006, s. 7).
} 
Här används klarspråk enbart i rubriken. En förklaring kan vara att just denna kurs uttryckligen vänder sig till dem som jobbar både inom privat och offentlig sektor och att målgruppen således är bredare än verksamma inom "offentlig verksamhet" (jfr dock den strävan att vidga användningen av benämningen klarspråk som tycks ligga bakom initiativet att utveckla en termdefinition, vilket vi diskuterade ovan). Att klarspråk å andra sidan alls används är intressant. En tolkning är att användningen är taktisk: den smygs in så att den som är införstådd med klarspråksdiskursen och söker efter just en klarspråkskurs ska hitta den, men också så att den som inte är införstådd inte ska avskräckas av en benämning som är okänd eller uppfattas som mindre relevant. På ett subtilt sätt anpassas således produkten till båda målgrupperna.

I marknadsföringen av andra produkter förekommer det att klarspråk inte alls nämns, trots att den produkt som presenteras - ofta en kurs - uppenbarligen kan associeras till myndighetsspråkvårdens arbete. Då kan andra markeringar av kopplingen till det språkpolitiska arbetet användas på ett likaledes subtilt sätt, som i följande exempel från ett produktblad respektive ett informationsblad från två olika företag:

\begin{abstract}
Skriv vårdat, enkelt och begripligt
På dagens arbetsplatser förväntas alla kunna formulera och utforma effektiva texter. På den här kursen får du lära dig hur det går till. Vi går igenom hur du ska uttrycka dig för att göra dina texter effektiva, begripliga och lättlästa, samt vilka regler och standarder som finns för utformning av olika dokument. (Ur produktblad för skrivkurs, företag 2)

Behöver du anlita en språkkonsult för professionell hjälp med dina texter? [Företagsnamn] erbjuder tjänster med inriktning mot textgranskning och språkrådgivning. Vi utformar och anpassar dina texter utifrån mottagarens behov och ser till att ditt budskap förmedlas på ett tydligt, vårdat och begripligt sätt. På klarspråk helt enkelt! (Ur informationsblad om företaget, företag 1)
\end{abstract}

I dessa exempel signaleras för den som är insatt en intertextuell koppling till det språkpolitiska arbetet. Genom rubriken "Skriv vårdat, enkelt och begripligt" hos det ena företaget och parafrasen "på ett tydligt, vårdat och begripligt sätt" hos det andra, alluderar man på formuleringen i språklagen ("Språket i offentlig förvaltning ska vara vårdat, enkelt och begripligt"). Återigen kan skälet vara taktiskt: texterna vänder sig till flera målgrupper. Benämningen klarspråk i det andra exemplet används på samma sätt som ovan beskrevs: så att det kan läsas som kopplat till klarspråksarbetet men också så att det kan läsas som ett positivt laddat allmänord.

Vi kan alltså i marknadsföringen urskilja en klar tendens att benämningen klarspråk används med försiktighet (i den mån den alls används). I materialen föredras allusioner på klarspråksarbete, snarare än explicit användning av benämningen.

\title{
Benämningen klarspråk $i$ utbildningen på kommunförvaltningen
}

En delvis annorlunda men lika taktisk användning av benämningen klarspråk framträder i utbildningen på den kommunala förvaltningen. Här nämns visserligen inte klarspråk mer än någon enstaka gång, men då på en mycket framskjuten plats i själva inledningen av utbild- 
ningen. Efter att ha etablerat kontakt med deltagarna presenterar kursledaren innehållet i utbildningen på följande sätt:

\begin{abstract}
de vi jobbar me de ja jobbar me e principerna för klarspråk å klarspråk e de arbete som har funnits i dom offentliga verksamheterna sen sjuttitalet egentligen $i$ å me dureformen å en jämlikhetssträvan att medborgarna ska ha rätt å begripa vad vi skriver å säger eh så har forskningen språkforskningen tagit fram eh ett antal faktor som vis- som gör texter asså f- vi har fått reda på lite mer va som gör en text mer begriplig mindre begriplig och de e utifrån den forskning som ja kommer me tips (.) till er
\end{abstract}

Precis som i marknadsföringsmaterialen kan man säga att klarspråk här används taktiskt. Det omnämns tidigt som ett slags etikett som talar till förförståelsen hos dem som är lojala med och insatta i klarspråksdiskursen, men förutsätter samtidigt inte en sådan förförståelse. Den som inte känner till det behöver inte fördjupa sig i det.

Klarspråk etableras därmed som en hävdvunnen bakgrundsfaktor, men diskuteras inte mera. Det kopplas här också till frågor om demokrati och rättssäkerhet men enbart i förbigående ("... att medborgarna ska ha rätt å begripa vad vi skriver å säger").

\title{
Hur motiveras strävan efter ett enklare (myndighets)språk?
}

Som vi har sett är själva benämningen klarspråk i dag en del av den politiska diskursen, men inte någon bärande del av genomförandet av detta språkpolitiska projekt, även om benämningen i vissa sammanhang verkar ha fått fäste som ett sätt att tala om ett (etablerat) sätt att genomföra det språkpolitiska projektet på. Nästa steg i vår analys handlar om hur de konkreta åtgärder, råd och rekommendationer som ska realisera det förändrade språkbruket motiveras.

\section{Motiveringar i språkpolitiska dokument}

Redan under tidigt 1980-tal sammanfattas i kommittédirektivet för Språkvårdsutredningen flera av de motiveringar och områden som senare ska återkomma (Kommittédirektiv "Översyn av språkvården inom statsförvaltningen” 1983, s. 3). Här definieras som ett par utgångspunkter att "ett begripligare myndighetsspråk gör det lättare för medborgarna att ta del av de regler, beslut, planer och upplysningar som kommer från myndigheterna". Detta motiveras med att det gynnar "det demokratiska samspelet mellan medborgarna och deras myndigheter”. Även rättssäkerheten berörs:

Det är även med hänsyn till rättssäkerheten av största vikt att myndigheterna använder ett lättbegripligt språk: det kan bidra till att allmänheten bättre kan ta till vara sina rättigheter och fullgöra sina skyldigheter.

Det hänvisas också till att "[e]tt bättre myndighetsspråk" även får betydelse "för kontakterna mellan myndigheter och enskilda på så sätt att läs- och tolkningstiden kan förkortas”, vilket också knyts till att ett bättre offentligt språk "kan göra myndigheternas verksamhet enklare och därmed billigare och mera rationell”. 
Redan här ser vi en ganska utförlig genomgång som omfattar flera av de motiveringar vi kommer att möta i den politiska sfären senare. Dessa har sammanfattats av språkvårdaren Barbro Ehrenberg-Sundin vid Regeringskansliet som stärkt demokrati, ökad rättssäkerhet, ökad effektivitet och minskade kostnader (2000, s. 170 f.) och är alltså ganska tydligt artikulerade redan i kommittédirektivet från 1983. Dessa motiveringar - samt en motivering om att begripligt språk ökar förtroendet för myndigheter - dyker sedan regelbundet upp i de dokument där det språkpolitiska arbetet motiveras. Exempelvis står det i betänkandet Värna språken - förslag till språklag (2008, s. 231 f.) följande:

Det är ett självklart krav att var och en som företräder det allmänna och utövar offentlig makt ska använda ett sådant språk som den enskilde medborgaren kan förstå. Detta är av grundläggande betydelse för den enskildes rättstrygghet och det är också en förutsättning för att myndigheter och andra organ som företräder det allmänna ska vinna medborgarnas förtroende.

Här motiveras ett visst språkbruk med rätten för den enskilda medborgaren att förstå, och det kopplas till rättstrygghet och förtroende. På andra ställen i samma betänkande (s. 110) utvecklas andra motiveringar, bl.a. utifrån "effektiviteten" i organisationen:

Begreppet klarspråk har under senare år kommit att stå för begripliga myndighetstexter och ett klart och mottagaranpassat myndighetsspråk. Att systematiskt arbeta med klarspråk kan ses som ett sätt att höja effektiviteten i organisationen och förbättra kommunikationen mellan myndigheter och medborgare. Det bör också innebära kompetensutveckling för medarbetarna.

Sammanfattningsvis framstår den primära motiveringen i de språkpolitiska dokumenten som entydig: att ett myndighetsspråk som är lätt att förstå för den enskilda medborgaren gynnar demokratisk insyn och delaktighet, ökar rättssäkerheten och förtroendet för det offentliga. Dessutom förekommer motiveringar om att mer lättlästa texter skapar ökad effektivitet och minskade kostnader. Dessa motiveringar förefaller vara sekundära, eftersom de alltid kommer $\mathrm{i}$ andra rummet, efter det att demokratiargumenten har presenterats.

\section{Motiveringar i språkvårdsföretags marknadsföringsmaterial}

Går vi så över till de kommersiella aktörernas själv- och produktpresentationer blir bilden mycket annorlunda. Vi såg redan i förra avsnittet några exempel ur detta material, där det framgick att klarspråk inte var något centralt begrepp, och även i jämförelse med motiveringarna i den politiska diskursen framträder tydliga skillnader. Sammanfattningsvis träder motiveringar knutna till demokrati och rättssäkerhet i bakgrunden när det gäller hur tjänsterna motiveras, medan effektivitet och lönsamhet blir mycket centrala frågor. Även förtroende kan tas upp, om än vanligtvis snarare vinklat mot kommersiellt varumärkesbyggande. Ett par exempel:

Det finns många vinster med att genomföra ett språkprojekt på företaget. Resultatet blir en enhetlig ton i företagets texter, effektivare skrivsätt och nöjdare kunder. För att inte tala om 
den personliga utvecklingen hos medarbetarna. Det är ju så kul att diskutera språk! (Webbsida om produkten "språkprojekt", företag 1)

Vi på [företagsnamn] är språkkonsulter och vi arbetar med att göra texter bättre. Bättre texter ökar din lönsamhet, bygger ett starkt varumärke och stärker förtroendet för dig och dina produkter eller tjänster. (Presentationstext om företaget, företag 2)

Det är värt att notera att företag 1 även framhåller en personlig vinst för deltagarna $\mathrm{i}$ form av personlig utveckling, samtidigt som det framställs som en förmån att få diskutera språk.

Det förekommer också att det uttryckligen skrivs om “enkelt språk” som en konkurrensfördel:

Många kunder avstår från att anlita en jurist för att de är oroliga att de inte ska förstå. Låt ett klart och enkelt språk bli en konkurrensfördel för din byrå och en ledstjärna för din organisation. (Produktblad för skrivkurs för jurister, företag 1)

I de kommersiella texterna motiveras alltså klarspråk utifrån argument som nöjda kunder, effektivitet i organisationen och personlig utveckling. Vinsterna med klarspråksarbetet är snarare för organisationen och skribenten och inte, som i de centrala dokumenten, för medborgarna.

\section{Motiveringar i utbildningen på kommunförvaltningen}

Går vi så till den tidigare nämnda utbildningen framträder ännu en ganska disparat bild. Det framgick redan ovan att motiveringar utifrån demokrati och rättssäkerhet antyds och underförstås i utbildningen och blir till en ganska osynlig bakgrund.

Sammanfattningsvis kan man säga att både kursledare och deltagare inom utbildningen orienterar sig mot användbara tips och råd för deltagarna i deras jobb. Ett återkommande råd är att skriva texter som "instruktioner" för medborgarna, med motiveringen att det får dem att göra det de ska (snarare än med motiveringen att de har rätt att förstå vad de förväntas göra). Att utbildningen hålls ur myndighetsmedarbetarnas perspektiv snarare än medborgarnas kan också illustreras av en passage där kursledaren introducerar språklagen:

sen har vi ju sen två år en språklag hur många av er känner till de

KURSLEDAREN RÄCKER UPP HANDEN

FLERA DELTAGARE RÄCKER UPP HANDEN

att de står rakt ut i språklagen elfte paragrafen språket i offentlig sektor verksamhet står de språket i offentlig verksamhet ska vara vårdat enkelt och begripligt (.) ni ska skriva enkelt (.) de står i lagen (.) även dom som ni ger uppdrag åt konsultfirmor å så vidare ska skriva enkelt (.) de vill säga ni ska kräva av dom (.) att dom skriver enkelt språk de står i lagen å skriver ni inte enkelt så kan ni få JO på er (.)

SKRATTAR de va en kommun som hade ut en nån slags böter eller va de nu heter till en privatperson för att de va nåt ja kommer inte ihåg hur de va om de va ett staket som va felbyggt eller så och jo sa de e helt rimligt att den här privatpersonen inte ska behöva betala den bötern för att de här brevet va så krångligt skrivet om hur man skulle göra så de e helt rimligt att bedöma att de fanns de a de va inte begripligt (.) så att den här persoprivatpersonen slapp å betala för att brevet var så pass obeskriv- obegripligt 
Motiveringen utgår således från myndighetsperspektivet, där en varnande berättelse illustrerar att om myndighetsmedarbetaren inte skriver tydligt så kan hen bryta mot språklagen och bli anmäld till Justitieombudsmannen (JO), med effekten att myndighetens beslut blir ogiltigförklarat.

Det som sker i utbildningen tycks utgöra ett möte mellan olika mål och motiveringar för förändringar i skrivandet. Det är delvis relaterat till det politiska språkprojektet, där de språkpolitiska målen om demokrati och rättssäkerhet finns som en förgivettagen fond för att legitimera klarspråksråden, men lokala mål - kopplade till uppdraget som anställd på kommunen blir mer centrala. Kursledaren orienterar sig alltså mot klarspråksarbetets ideal om demokrati och rättssäkerhet, men vinklar samtidigt innehållet utifrån att det är användbara råd och tips för att de anställda ska göra sitt jobb bättre. Det verkar fungera som ett sätt att föregripa motstånd som kan uppstå i konflikt med andra mer lokala språkliga agendor. En slutsats blir att det politiska klarspråksprojektet här realiseras som något som primärt ger lösningar på lokala behov i deltagarnas arbete, medan den starkt ideologiska dimension som finns i den politiska sfären sjunker undan.

Detta blir också belyst av den intervju som vi har gjort med en av kursdeltagarna. Deltagaren är generellt positiv till utbildningen, men beskriver sin behållning av den just som användbara "tips och råd" och "småknep" i skrivandet, relaterade till strävan efter att utveckla sitt sätt att skriva och utföra sitt arbete på ett effektivt sätt i rollen som handläggare (inte att uppnå en demokratisk statsförvaltning eller liknande).

För att sammanfatta: Motiveringar utifrån demokrati och rättssäkerhet diskuteras inte, men finns som en underförstådd bakgrundsfaktor, som kan uppfattas av den som redan är insatt. Det dominerande är att både kursledare och deltagare är orienterade mot tips och råd och det användbara för deltagarna i deras jobb. Grundmotivet är inte att bättre skrivande är demokratiskt gynnsamt eller mer rättssäkert, utan att det gör att medarbetarna kan göra sitt jobb effektivare genom att få medborgarna att göra det de ska. Kursledaren ger själv i utbildningen också uttryck för en delvis motsägelsefull förståelse av syftet med utbildningen och legitimerar den på flera sätt parallellt, medan deltagaren tydligt prioriterar sitt eget språkprojekt: att samla redskap för att nå målet med sitt arbete.

\section{Sammanfattning}

Vår rapsodiska genomgång ger kanske inte någon fullt ut representativ bild av den svenska myndighetsspråkvården. Vad den dock kan visa är hur heterogent och undflyende ett språkpolitiskt projekt som detta blir när det följs från politiken till genomförandekontexterna. Är det ens att se som ett språkpolitiskt projekt? Genomgången kan sägas visa på hur diskursen inom den politiska sfären i hög grad omformas - och delvis saknar motsvarigheter - i de lokala genomförandekontexterna, där de tycks konkurreras ut av andra mer lokala nyttor och motiv.

Sammanfattar vi hur det ser ut i den politiska sfären framstår myndighetsspråkvården som en (i dag) etablerad självklarhet. Den framstår också som ett utpräglat demokratiprojekt, som visserligen gärna ska ge ökad effektivitet och bättre service men ytterst ska leda till ökat förtroende för de demokratiska instanserna och gynna medborgarnas aktiva deltagande. 
Ser vi på genomförandekontexterna tycks demokratiaspekten sjunka undan. I marknadsföringsmaterial kan klarspråk som benämning användas som ett slags signalord som talar till dem som letar efter det, men motiveringar handlar aldrig om demokrati och rättssäkerhet. I stället är det motiveringar om effektivitet och minskade kostnader som tas upp, kompletterat med argument om marknadsföringsfördelar - och motiveringar om att ett utvecklat språkbruk för den enskilda också innebär personlig utveckling.

I utbildningen på den kommunala förvaltningen är förhållandena komplexa. Det politiska demokratiprojektet blir här en underförstådd bakgrundsfaktor - demokratiska motiv nämns i förbigående och kan eventuellt underförstås även i andra delar av utbildningen - men det viktigaste blir att lösa skribenternas problem "här och nu". Kursledaren orienterar sig mot att ge "tips" ur ett perspektiv som är mycket lojalt med kursdeltagarnas, och det är också framför allt praktiska "småknep" som blir behållningen för den kursdeltagare vi har intervjuat.

Således: på den politiska nivån verkar alla entydigt veta vad meningen med det förändrade myndighetsspråket är - nämligen demokrati, rättssäkerhet, effektivitet - och dessutom vara eniga om detta (jfr även Nord 2014). Detta ifrågasätts visserligen aldrig direkt i genomförandenivån, men däremot framträder konkurrerande mål och motiv som tycks ta över. Vi har inte sett några tecken på aktivt motstånd. Däremot tycks motstånd föregripas genom de motiveringar som väljs i språkföretagens marknadsföring och i utbildningen, vilket antyder att det förväntas finnas ett mått av aktivt eller passivt motstånd i genomförandet.

\section{Avslutande reflektioner}

Vår undersökning visar arbetet för ett enklare myndighetsspråk som ett mångfasetterat och möjligen även splittrat projekt. Detta är inte förvånande; erfarenheter från många andra typer av språkpolitiska (och för den delen allmänpolitiska) projekt är att genomförandet ofta är något helt annat än planen eftersom så många påverkande lokala faktorer finns. Vi menar ändå att de iakttagelser vi här har gjort är relevanta att reflektera över för den som arbetar praktiskt med myndighetsspråkvård, dels för att medvetandegöra vad det är som kan påverka om arbetet kan genomföras effektivt, dels för att bevaka att inte viktiga aspekter går förlorade i genomförandet.

För det första vill vi peka på hur viktigt det är att i genomförandeinsatser vara medveten om att deltagarna ofta har sina egna lokala språkliga projekt, som innebär att de har sina egna motiv för att vilja förändra (eller inte förändra) sitt sätt att skriva, och att dessa ibland (men förstås inte alltid) kan hamna i konflikt med motiven för språkpolitiska demokratiprojekt. En medvetenhet om att projektet uppfattas på olika sätt i skilda sammanhang är därför en förutsättning för den som arbetar praktiskt, eftersom det ger större beredskap för att möta människor i deras egna språkliga projekt, och att möta och förstå det motstånd och de problem som kan uppstå i genomförandet. Motståndet behöver ju inte vara aktivt och bottna i att den enskilda skribenten motsätter sig medborgarnas rätt att förstå texter som berör dem. Tvärtom är det nog ovanligt att det demokratiska idealet som sådant ifrågasätts. Däremot torde det vara vanligt med olika typer av passivt motstånd, som bottnar i ovilja att förändra befintliga rutiner och vanor. 
För det andra vill vi peka på vad som riskerar att gå förlorat i anpassningen till lokala förutsättningar. Det är lätt att tänka att lokalanpassningen är en naturlig och oundviklig följd av villkoren för arbetet, och att enda sättet att hantera de lokala projekten och agendorna är att anpassa sig till dem. I många avseenden är säkert denna anpassning helt nödvändigt. Det är ju sannolikt omöjligt att driva någon mer omfattande verksamhetsförändring genom t.ex. en halvdagsutbildning. Icke desto mindre tycker vi oss se en risk med denna typ av anpassning. Vi menar att det språkpolitiska arbetet riskerar att tunnas ut och förlora sin större mening om det reduceras till att bara bli ett projekt för att skriva lite bättre på jobbet. Det finns ytterst ändå en motsättning mellan "råd och tips" helt på skribentens villkor - och ett ideal om "klarspråk" som potentiellt ifrågasätter verksamheter i sin grund, genom att utmana lokala agendor och aktivt tackla motstånd som bottnar i rutiner och vanor. Kanske vore ändå demokratiaspekterna värda att ge lite större utrymme vid sidan av mer lokalanpassade motiveringar?

Avslutningsvis vill vi också lyfta fram att vi ser ett stort behov av ytterligare forskning som belyser de praktiska sidorna av detta språkpolitiska arbete utifrån tidigare erfarenheter inom språkplaneringsforskningen. Redan vår begränsade genomgång har gett underlag för att lyfta flera principiellt viktiga frågor, och mer djupgående undersökningar skulle kunna ge gott underlag för systematiska reflektioner - liksom också för en fördjupad dialog mellan forskare och professionellt verksamma språkvårdare.

\section{Referenser}

\section{Analyserat politiskt material}

Kommittédirektiv “Översyn av språkvården inom statsförvaltningen”. (Dir 1983:49.)

Klarspråk - en grund för god offentlig service 1985. Språkvårdsutredningens rapport. Civildepartementet. (Ds C 1985:3.)

Regeringens proposition 1985/86:80 om ny förvaltningslag.

Mål i mun. Förslag till handlingsprogram för svenska språket 2002. Betänkande av Kommittén för svenska språket. (SOU 2002:27.)

Bästa språket - en samlad svensk språkpolitik. Regeringens proposition 2005/06:2.

Värna språken - förslag till språklag 2008. Betänkande av Språklagsutredningen. (SOU 2008:26.)

Språk för alla - förslag till språklag. Regeringens proposition 2008/09:153.

\section{Analyserat material från språkvårdsföretag}

Företag 1, Språkkonsulterna. http://www.sprakkonsulterna.se. Hämtad 2013-11-12.

Företag 2. Bättre text http://battretext.se. Hämtad 2013-11-12.

Företag 3. Klarspråka http://klarspraka.se. Hämtad 2013-11-12.

Företag 4. Expressiva. http://expressiva.se. Hämtad 2013-11-12.

\section{Litteratur}

Baldauf, R. B. Jr. (2006). Rearticulating the Case for Micro Language Planning in a Language Ecology Context. Current Issues in Language Planning, 7(2-3), 147-170.

Becker Jensen, L. (1998). Kancellistil eller Anders And-sprog? En undersøgelse afforvaltningssproget og dets institutionelle betingelser (2. udg.). Frederiksberg: Roskilde Universitetsforlaget.

Becker Jensen, L. (2007). Klarsprog - kommunikationsteknik eller holdningsændring? I P. Jarvad \& I. E. Mørch (Red.), Klart sprog er godt sprog. Rapport fra en nordisk konference om klarsprog. Gilleleje 15.-17. november 2006 (s. 11-23). U.o.: Dansk Sprognævn.

Bendegard, S. (2014). Begriplig EU-svenska? Klarspråksarbetets förutsättningar inom den interinstitutionella översättningsprocessen. Uppsala: Institutionen för nordiska språk, Uppsala universitet. 
Bendegard, S. (2015). Klarspråksarbetets villkor i samband med EU:s rättsaktsöversättning. Sakprosa, 7(2), art. 3. https://www.journals.uio.no/index.php/sakprosa/article/view/981

Berthoud, A.-C. \& Lüdi, G. (2011). Language policy and planning. I R. Wodak, B. Johnstone \& P. E. Kerswill (Red.), The SAGE handbook of sociolinguistics (s. 479-495). Los Angeles: SAGE.

Canagarajah, S. (2006). Ethnographic methods in language policy. I T. Ricento (Red.), An introduction to language policy. Theory and method (s. 153-169). Malden: Blackwell.

Cooper, R. L. (1989). Language planning and social change. Cambridge: Cambridge University Press.

Ehrenberg-Sundin, B. (2000). Internationellt klarspråksarbete - en grund för bättre EU-texter?. I B. Melander (Red.), Svenskan som EU-språk (s. 144-177). Uppsala: Hallgren \& Fallgren.

Förvaltningslagen (1986:223).

Hjalmarsson, H. E. \& Nicolay, K. (2010). Training for Plain Language. Clarity, 64, 26-32.

Hornberger, N. H. \& Johnson, D. C. (2007). Slicing the Onion Ethnographically. Layers and Spaces in Multilingual Language Education Policy and Practice. TESOL Quarterly, 41(3), 509-532.

Jarvad, P. \& Mørch, I. E. (Red.). (2007). Klart sprog er godt sprog. Rapport fra en nordisk konference om klarsprog. Gilleleje 15.-17. november 2006. København: Dansk Sprognævn.

Josephson, O. (2009). Klarspråksforskningens framtid. I C. Nyström Höög (Red.), Medborgare och myndigheter (s. 100-107). Uppsala: Uppsala universitet.

Kjærgaard, A. (2010). Sådan skriver vi-eller gør vi? En undersøgelse af de tekstlige effekter af to sprogpolitiske projekter i Danmarks Domstole og Københavns Kommune og af årsagerne til projekternes gennemslagskraft. København: Københavns universitet.

Kjærgaard, A. (2012). Fra lidenskab til ligegyldighed. En caseanalyse fra Danmarks Domstole af et sprogpolitisk projekts (manglende) gennemslagskraft. Sakprosa, 4(1), art. 1.

https://www.journals.uio.no/index.php/sakprosa/article/view/210

Klarspråk lönar sig (2006). Handbok för ett effektivt klarspråksarbete. Stockholm: Norstedts juridik.

Klarspråk lönar sig (2013). Handbok för ett effektivt klarspråksarbete (2 uppl.). Stockholm: Norstedts juridik.

Lind Palicki, L. (2014). Klarspråk - demokratiprojekt, kvalitetsmätning eller "småtips" i arbetet? I M. Andersson, E. Sommardahl \& A. Piehl (Red.), Myndighetstexter ur medborgarperspektiv. Rapport från Nordisk klarspråkskonferens i Helsingfors 21-22.11.2013 (s. 11-16). Helsingfors: Institutet för de inhemska språken.

Lind Palicki, L. \& Nord, A. (2013). "Ni ska skriva enkelt - det står i lagen”. Legitimeringar av klarspråk i en utbildning för myndighetsskribenter. I C. Rosén, P. Simfors \& A.-K. Sundberg (red.), Språk $i$ undervisning. Rapport från ASLA:s vårsymposium Linköping, 11-12 maj, 2012 (s. 37-47). Linköping \& Växjö: ASLA, Svenska föreningen för tillämpad språkvetenskap.

Nord, A. (2011a). Att göra någon annans text tydlig. En studie av språkbearbetningen av en myndighetstext. (TeFa 48.) Uppsala: Uppsala universitet.

Nord, A. (2011b). Att revidera andras texter. Språkgranskning som en del av myndighetsskrivandet. I A.-C. Edlund \& I. Mellenius (Red.), Svenskans beskrivning 31. Förhandlingar vid Trettioförsta sammankomsten för svenskans beskrivning, Umeå den 20-21 maj 2010 (s. 252-262). Umeå: Umeå universitet.

Nord, A. (2013). "De e du som e experten”. Roller, normer och perspektiv i ett textsamtal mellan en språkvårdare och en skribent i myndighetsmiljö. I B. Bihl, P. Andersson \& L. Lötmarker (Red.), Svenskans beskrivning 32. Förhandlingar vid trettioandra sammankomsten för svenskans beskrivning, Karlstad den 18-19 oktober 2011 (s. 222-233). Karlstad: Karlstads universitet.

Nord, A. (2014). Högtidstal men ingen debatt? Det svenska klarspråksarbetet som samtida språkpolitiskt projekt. I J. Lindström, S. Henricson, A. Huhtala, P. Kukkonen, H. Lehti-Eklund \& C. Lindholm (Red.), Svenskans beskrivning 33. Förhandlingar vid Trettiotredje sammankomsten för svenskans beskrivning. Helsingfors den 15-17 maj 2013 (s. 333-342). Helsingfors: Helsingfors universitet.

Nyström Höög, C. (2009). Textvård mellan två kulturer. I C. Nyström Höög (Red.), Medborgare och myndigheter (s. 7-14). Uppsala: Uppsala universitet.

Nyström Höög, C. (2010). Kursändring i klarspråksarbetet? Om myndighetsspråkvård och språkforskning. I L.G. Andersson, O. Josephson, I. Lindberg \& M. Thelander (Red.), Språkvård och språkpolitik. Svenska språknämndens forskningskonferens i Saltsjöbaden 2008 (s. 120-138). Stockholm: Norstedts.

Nyström Höög, C., Söderlundh, H. \& Sörlin, M. (2012). Myndigheterna har ordet. Om kommunikation i skrift. Stockholm: Norstedts.

Nyström Höög, C., Söderlund, H. \& Sörlin, M. (2012a). Klarspråk och myndigheters texter - sammanfattning och slutord. I C. Nyström Höög, H. Söderlundh \& M. Sörlin (Red.), Myndigheterna har ordet. Om kommunikation i skrift (s. 155-168). Stockholm: Norstedts. 
Nyström Höög, C., Söderlund, H. \& Sörlin, M. (2012b). Myndigheters texter och klarspråksarbete. I C. Nyström Höög, H. Söderlundh \& M. Sörlin (Red.), Myndigheterna har ordet. Om kommunikation i skrift (s. 13-34). Stockholm: Norstedts.

Nämnd, inte glömd. Historik över Nämnden för språkvård och Svenska språknämnden 1944-2007. (2007). Stockholm: Norstedts.

Rikstermbanken (2013). Länk: http://www.rikstermbanken.se/rtb/visaTermpost.html?id=219486. Hämtad 201311-06.

Schriver, K. \& Gordon, F. (2010). Grounding plain language in research. Clarity, 64, 33-39.

Spolsky, B. (2004). Language policy. Cambridge: Cambridge University Press.

Språklag (2009:600).

Språkrådet (odaterat) = Klarspråk - för ett begripligt offentligt språk. Hämtat 3 september 2014 från http://www.sprakochfolkminnen.se/klarsprak

Teleman, U. (2003). Tradis och funkis. Svensk språkvård och språkpolitik efter 1800. Stockholm: Norstedts.

Teleman, U. (2005). Language cultivation and language planning II: Swedish. I Bandle, Oskar (red.), The Nordic Languages: An International Handbook of the History of the North Germanic Languages (s. 19701983). Berlin: de Gruyter.

Texter för medborgarna - hur vet man om de är bra? (2005). Resuméer av föreläsningarna på Klarspråkskonferensen 20 maj 2005. Regeringskansliet.

Visst går det att förändra myndighetsspråket! (1993). En rapport från Språkvårdsprojektet. Stockholm: Allmänna förlaget. 